Article

\title{
Correlation of Infrared Thermal Imaging Results with Visual Inspection and Current-Voltage Data of PV Modules Installed in Kumasi, a Hot, Humid Region of Sub-Saharan Africa
}

\author{
Gabriel Takyi \\ Mechanical Engineering Department, College of Engineering, Kwame Nkrumah University of \\ Science \& Technology, Kumasi, Ghana; gabrieltakyi@yahoo.co.uk
}

Received: 21 August 2017; Accepted: 12 October 2017; Published: 18 October 2017

\begin{abstract}
In this study, a photovoltaic (PV) modules site installed from 1997 to 2017 (20 years of outdoor exposure) in the hot, humid region of Kumasi, Ghana in Sub-Saharan Africa was selected in order to study the aging phenomenon and rate of degradation due to long-term exposure. The main purpose of this work was to correlate the performance of $14 \mathrm{PV}$ modules using data from infra-red thermal imaging (hot spot tests), current-voltage (I-V) tests and visual inspection. The modules were first visually inspected followed by electrical performance tests using an I-V curve tracer. Hot spot testing of each module was performed to enable further characterization. The results of the visual inspection using the United States National Renewable Energy Laboratory (NREL) checklist did not show any major observable defects. The results also show that the higher the temperature difference in the hot spot tests, the higher the rate of power degradation. Eleven modules failed the hot spot tests according to the criteria indicated in the literature. The average power degradation rate was $1.36 \%$ /year, which is above the industry-accepted range of $0.7-1.0 \%$ /year. The results provide evidence of a positive correlation between temperature difference and performance parameters such as power degradation (Pdeg), power performance factor (PPF) and power drop (Pdrop). The power performance factor for all 14 modules fell below the average $80 \%$ standard set by most manufacturers for modules operating within the 25-year warranty.
\end{abstract}

Keywords: infrared thermal imaging; performance degradation; I-V data

\section{Introduction}

The global acceptance of solar photovoltaic (PV) has motivated several studies into the design and performance of PV systems. Performance parameters are based on globally accepted standards designed by agencies such as the National Renewable Energy Laboratory (NREL), etc., as reported in the literature [1]. Reduction in the performance of PV modules over a period of time is becoming a great concern for stakeholders within the renewable energy (RE) market. Factors that account for a drop in performance have been noted such as location of use, manufacturing companies (technologies involved), age and basic maintenance issues, as reported by Jordan et al. [2] and NREL [3]. Critical steps are being taken to monitor PV production and handling in other to minimise these setbacks. Manufacturing companies are also keen in ensuring their products' quality after years of use. In achieving this, warranties are becoming a competitive factor in the market. Several studies including Jordan et al. [2] and Phono [4] have assessed different manufacturing companies and their improved methods of giving out warranties over the years. Current PV research focuses on achieving high utilization factors and optimum performance of PV systems. Tsanakas et al. [5] report that the performance and lifetime of PV modules are influenced by defects originating either in the module's manufacturing processes or in the field. 
Canadian Solar has recently set warranties for its modules. For polycrystalline modules, it asserts that, for the first year of operation, Canadian Solar recommends an actual power output of not less than $97.5 \%$ and establishes an annual decline of not more than $0.7 \%$ [6]. Within a period of two to 25 years of operation, the power will not be less than $80.7 \%$ [6]. LG Solar [7] provides $80.2 \%$ power output at the end of the 25 years. Similar but not identical warranty statements are given by other manufacturers, as evidenced in the literature $[4,8-10]$. It should be noted, however, that all manufacturers agree that warranties will not apply to modules that have been neglected, misused, mishandled or improperly installed within these set periods. Roumpakias et al. [11] have stated that the degradation rate of PV system is less than $1 \%$ per year on the majority of systems.

According to the work reported by Parretta et al. [12], the reflectance method under diffused light was used to observe the optical properties of c-Si PV modules. It was observed that the optical properties are strongly affected by long-term outdoor exposure. Discoloration of the central region of cells and formation of large stains distributed over the modules' surface was observed. The degraded modules show an increase in their optical loss by reflectance under diffuse light. Spectral reflectance under direct light shows the degradation of the anti-reflectance coating (ARC) layer. As regards ethylene vinyl acetate (EVA) degradation, the expected products of degradation are lactones, ketones and acetaldehydes. Degradation should change the colour of EVA by producing yellowish or brown stains.

In the literature $[4,8,9]$, warranties can only be claimed after testing the performance of modules, which includes the overall power output. There are several parameters that affect the performance (mostly but not limited to power output) of PV systems. These performance parameters (also known as current-voltage (I-V) parameters) are essential in establishing the module degradation rate, which in turn can be used to establish warranty claims for modules, as reported by NREL [3]. These parameters include short circuit current $\left(\mathrm{I}_{\mathrm{SC}}\right)$, open circuit voltage $\left(\mathrm{V}_{\mathrm{OC}}\right)$, maximum power $\left(\mathrm{P}_{\max }\right)$, fill factor $(\mathrm{FF})$ and power performance factor (PPF). In analysing the I-V parameters, key curve deviations are considered and studied in detail in Section 1.1.

\subsection{I-V Curve Tracing}

One of the deviations in I-V curve tracing is the production of stepped curves. This may occur when bypass diodes activate and allow current around cells that do not receive enough light or have been weakened. Possible causes may include shading, soiling of damaged cells, etc. Roumpakias et al. [11] have reported that in a string of modules, this deviation can lead to a drop in the recorded current. Figure 1 shows typical arrays, with a stepped curve as a result of cell shading.

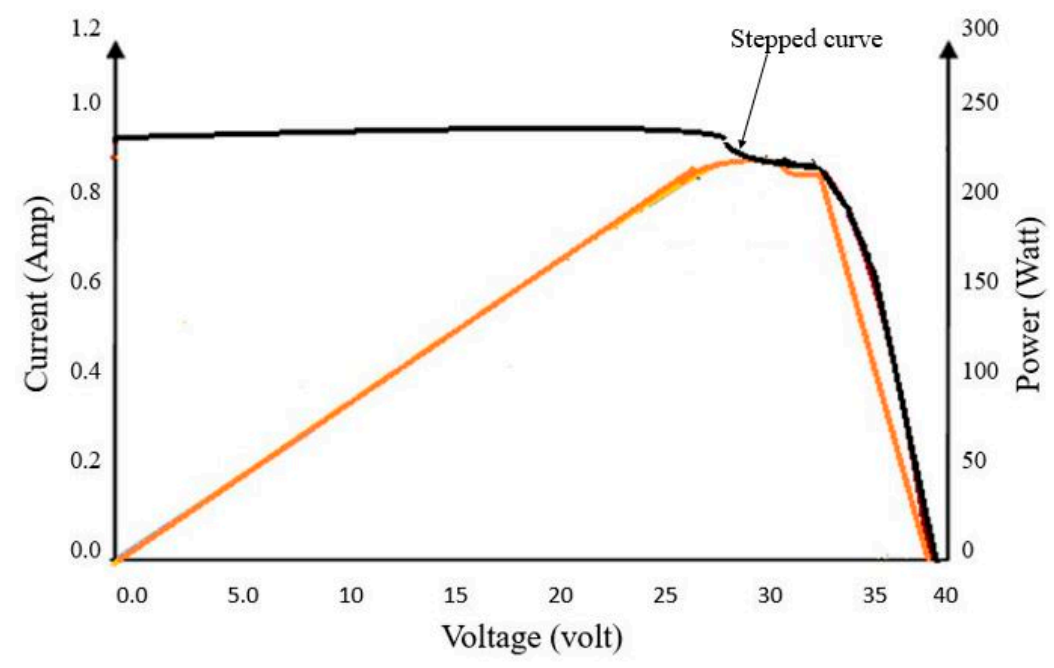

Figure 1. Step curve due to shading. 
Another deviation occurs where slopes along the I-V curve appear steeper than the manufacturer's curve. For steeper curves, reduced shunt resistance is a possible cause. Shunt current is a current that bypasses the solar cell junction without producing power, short circuiting a part of a cell or module. Some amount of shunt current within a solar cell is normal, although higher quality cells will have a higher shunt resistance and hence lower shunt current. Shunt current is typically associated with highly localized defects within the solar cell, or at cell interconnections. Infrared imaging of the PV module can usually identify minor shunt current hot spots since a temperature rise of $20^{\circ} \mathrm{C}$ or more is common. Factors that lead to a reduction in shunt resistance may include shunt paths existing in PV cells, shunt paths existing in the PV cell interconnects and module ISC mismatch. In the work presented by Solmetric [13], it is reported that the overall effect is the reduction in the fill factor of modules. Figure 2 shows various losses that can exist within I-V curves. These losses greatly affect the overall power output of modules as reported in the literature [11,13].

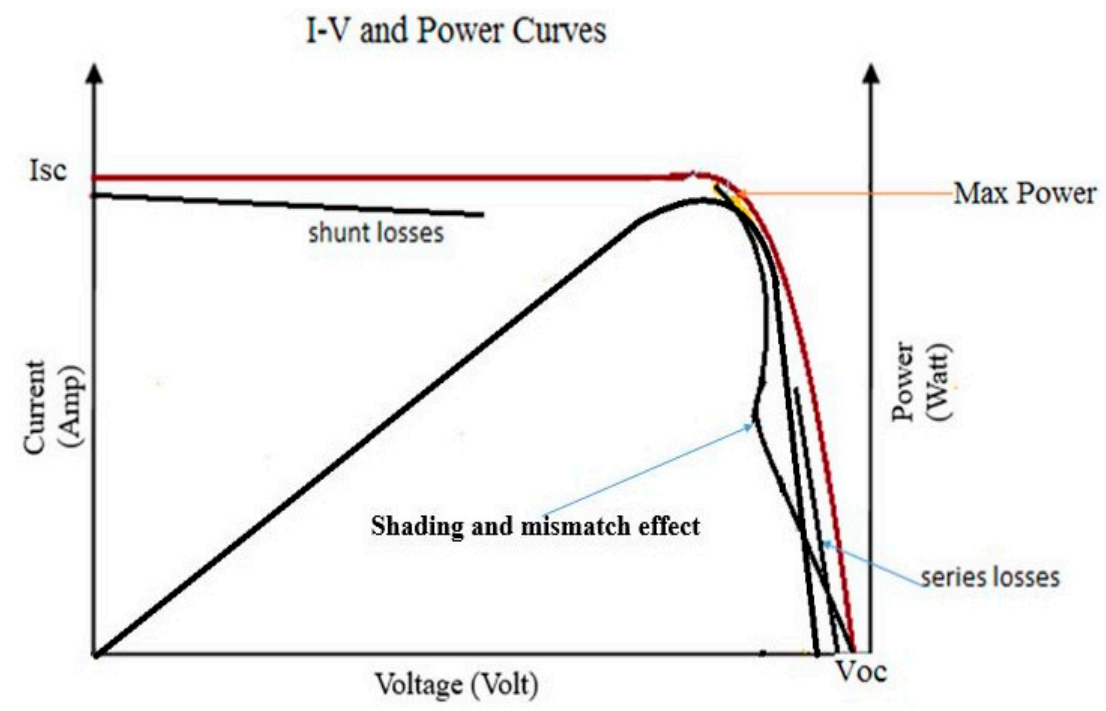

Figure 2. Possible losses within PV modules.

In a study conducted at NREL, a 17-year-old module's performance was tested and the results indicated a less than $0.5 \%$ decrease in maximum power per year. This was attributed to a reduction in $\mathrm{ISC}_{\mathrm{SC}}$ as indicated by the I-V curve reported in the study [14]. A similar study to determine the degradation rate was conducted and the average annual power degradation rate of PV modules was around $1.5 \%$. This degradation rate, according to the study [12], was a result of increased series and decreased shunt resistances affecting both current at maximum power (Imp) and voltage at maximum power (Vmp) and causing graph slopes to deviate.

\subsection{Low and High Short Circuit Current and Open Circuit Voltage}

Common I-V curve deviations include $\mathrm{I}_{\mathrm{SC}}$, and $\mathrm{V}_{\mathrm{OC}}$ values lower than the manufacturer's. For lower $\mathrm{V}_{\mathrm{OC}}$, the following can be possible causes:

- $\quad$ higher PV module temperature;

- $\quad$ shaded cell or module;

- shorted or conducting bypass diodes.

Osterwald [15] reported that the possible effect of a decrease in $V_{O C}$ is an increase in the rate of degradation because $\mathrm{V}_{\mathrm{OC}}$ and Pmax are greatly temperature dependent. Roumpakias et al. [11] indicate that $\mathrm{V}_{\mathrm{OC}}$ has one of the lowest aging rates in the performance parameters and so other factors should be considered as well in establishing the rate of degradation of modules. For ISC values lower than the manufacturer's, possible causes include: 
- the PV array is soiled (especially uniformly);

- $\quad$ PV modules are degraded.

Performance assessment is necessary for standardizing PV modules that are sold on the market and establishing warranty claims. In this paper, detailed tests and analyses are conducted on PV modules to assess key performance parameters such as $\mathrm{V}_{\mathrm{OC}}, \mathrm{I}_{\mathrm{SC}}, \mathrm{P}_{\max }, \mathrm{FF}, \mathrm{PPF}$, etc. under the hot-humid climatic conditions at the College of Engineering, Kwame Nkrumah University of Science and Technology (KNUST), Kumasi, Ghana (located in sub-Saharan Africa) to ascertain the degradation rates for polycrystalline PV technology. Thermal imaging tests are also conducted and correlated with the I-V data in order to obtain a complete profile of the cause of degradation.

A number of studies in the literature $[5,12]$ have reported the defects associated with fielded PV modules as well as in recently installed modules $[16,17]$ using optical and thermal observations. According to IEC 61215 and as reported in the literature [18], the parameters for detecting degradation include defects in insulation and leak currents and visual detection. Rompakias et al. [11] present a systematic compilation of detection along with a simple procedure to spot them using optical and infrared inspection as well as electrical inspection. The rapid growth of the PV sector has led to the need for extensive monitoring of the installation for defects.

In the work reported by Quansah et al. [19], similar to this paper, the rate of degradation was not computed and there was also no comparative analysis of degradation and hot spots. In this study, a PV module site used from 1997 to 2017 (20 years of outdoor exposure) in a hot, humid region in Kumasi, Ghana (Sub-Saharan Africa) was selected in order to study the aging phenomenon and degradation due to long-term exposure. The main purpose of this work is to correlate the performance of PV modules installed using data from infrared thermal imaging (hot spot tests), current voltage (I-V) tests and visual inspection. Generally, there is a lack of data in the literature on PV performance in sub-Saharan Africa and it is anticipated that this paper will provide useful data with regards to PV performance in that region.

\section{Methodology}

This section considers the approach used in conducting the study and experiments.

Fourteen polycrystalline PV modules manufactured by ASE GmbH (Putzbrunn, Munich Germany), installed on the top of the solar laboratory of KNUST, in a hot, humid region of West Africa, were chosen for this study in order to determine the level of degradation due to prolonged exposure to sub-Saharan climatic conditions. The modules were previously connected to provide electricity for the solar laboratory. The modules consist of 36 cells at a nominal power of 50 watts mounted on metallic frames at an angle of $15^{\circ}$ to the horizontal. Experimental work on the effect of angle of incidence and spectral profile on irradiance and power output is currently being undertaken by one of our project students and will be reported when completed. The module materials are tempered glass, EVA, polymer back sheet and aluminium frame. Three main experiments were conducted: physical inspection, I-V curve tracing and infrared imaging. The purpose of these tests is to enable us to obtain a complete profile of the performance of the various modules selected. After these tests, detailed analyses were performed on the results obtained. Finally, a degradation rate was calculated for each PV module.

\subsection{Experimental}

The key tests and experiments conducted on the selected PV modules include:

\section{- I-V Curve Tracing}

I-V curve tracing is a method of analysing the performance of a PV module or array, ideal for testing all the possible operating points of a PV module or string of modules. The equipment used for this experiment was a TRI-KA TRITEC analyser in conjunction with TRI-SEN sensing from Basel, 
Switzerland. The characteristic curve measured by the TRI-KA can be converted to a STC characteristic curve based on the values measured by the sensor TRI-SEN and displayed. In addition, the STC ideal characteristic I-V curves of PV module manufacturers can be displayed, due to the integrated module database. The TRI-SEN measures the irradiation, cell temperature and angle of inclination. The measured data are wirelessly transferred directly to the TRI-KA. The data are used to convert the characteristic curve measured by the TRI-KA into a STC characteristic curve (STC-Standard Test Conditions: irradiation $1000 \mathrm{~W} / \mathrm{m}^{2}$, spectrum air mass $(\mathrm{AM})=1.5$, module temperature $25^{\circ} \mathrm{C}$ ). A polycrystalline reference cell was used for measuring the irradiation.

The TRI-KA characteristics analyser measures and computes the following performance parameters as output:

1. Open-circuit voltage $\left(\mathrm{V}_{\mathrm{OC}}\right)$

2. Short-circuit current ( $\left.\mathrm{I}_{\mathrm{SC}}\right)$

3. I/V characteristic curve

4. STC characteristic curve

5. STC values

6. Fill factor

7. Ideal characteristic curve of module manufacturer

The modules were first disconnected and cleaned with a piece of cotton fabric to remove dust and visible dirt. The modules were then connected to the testing instruments. A minimum irradiation of $800 \mathrm{~W} / \mathrm{m}^{2}$ was attained before I-V curves were traced using test kits. All 14 modules were tested individually and reports generated. Three main curves were generated for each module:

(1) Curves from raw data derived from ground measurement (shown in green graph);

(2) Curves extrapolated to STC (shown in red graph);

(3) Ideal manufacturer's curve (shown in blue graph).

For the purposes of analysis, the extrapolated results were used in all comparisons with the ideal curve since it assumed the STC conditions as used by manufacturers. This approach is necessary in other to conduct a fair analysis of PV modules, as indicated in the literature [13,15]. The performance parameters recorded were compared with the ideal conditions in order to identify irregularities and degradation.

\section{- Visual Inspection of Modules}

Visual inspection conducted on the modules was based on criteria outlined by NREL. The data collection tool provided by NREL highlighted specific PV module failure mechanisms. The following failure modes were considered in this study:
a. Front Glass Damage (Superstrate)
b. Backsheet
c. Wires/Connectors
d. Junction Box
e. Metallization Browning
f. Encapsulant Browning
g. Cell damage
h. Cell delamination
i. Cell discoloration 


\section{- Infrared Imaging}

Defects such as cracks or interconnection mismatches in solar cells are a genuine problem for PV modules. They are hard to avoid and it is impossible to quantify their impact on module's performance during their lifetime. In the literature [5], it is reported that as a field module ages and is subjected to thermal and mechanical stresses, repeated relative movement of the crack results in electrical separation and an inactive cell with significant hot spot heating effect.

In the research work reported by Gallon et al. [20] and Kumar et al. [21], hot spots, which are areas on the module with high temperatures, were used as effective indicators to diagnose the defective portions of a PV module. Infrared images of module surfaces were captured using thermal imager Ti400 (Fluke Corporation, Everett, WA, USA). Figure 3 shows an image of a module using the fluke thermal imager. This experiment observed the surface of all modules individually whilst short-circuited. The purpose was to observe temperature distribution over the surface of the PV module. Two temperature points (hottest and coldest) were noted by moving the scanner across each cell of the modules. The measurements were taken during a period of good insolation (around $1000 \mathrm{~W} / \mathrm{m}^{2}$ ) in a clear sky. Hoyer et al. [22] and Acciana et al. [23] have classified hot spots as either a light hot spot, where power losses are about $4 \%$ due to a $10{ }^{\circ} \mathrm{C}$ temperature difference, or a strong hot spot, where power losses are about $18^{\circ} \mathrm{C}$ in the cell's surface. The accuracy of the infrared (IR) temperatures was verified using contact temperature probes. Figure 4 shows the experimental setup used to collect data to compare the IR imager and temperature probe readings. Table 1 shows the data taken from the IR imager and the four temperature probes. The results indicate that the data from the two measurement instruments compare favourably well.

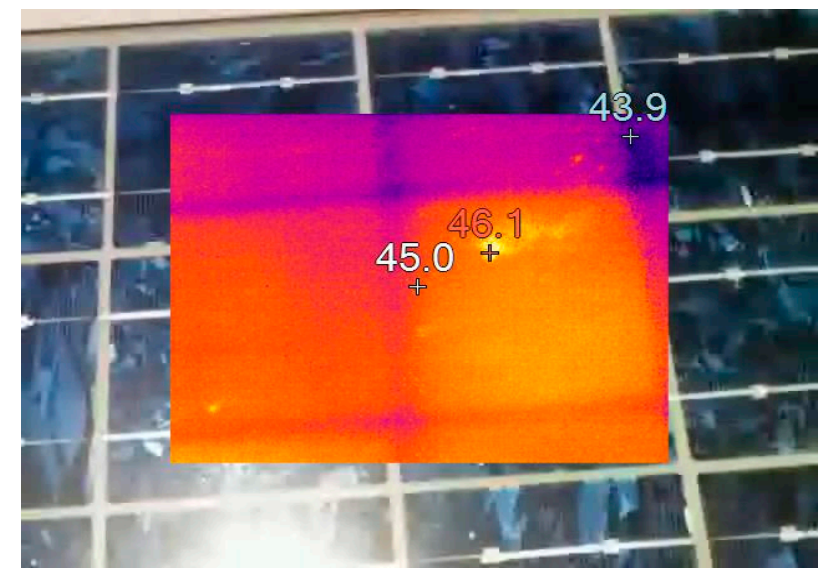

Figure 3. IR thermal image of a cell.

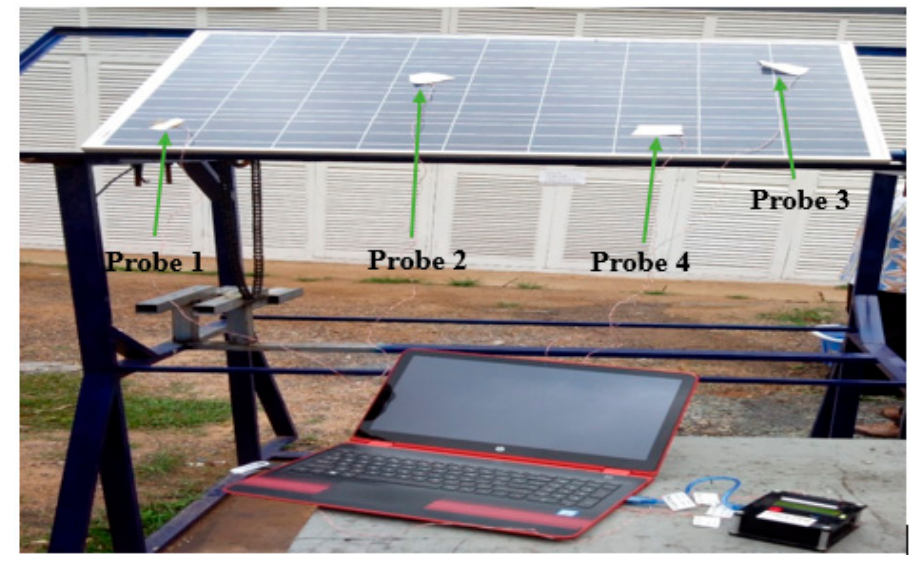

Figure 4. Setup for comparison of IR imager and temperature probes. 
Table 1. Results of IR imager temperature and temperature probe readings.

\begin{tabular}{ccc}
\hline PV Module Location/Probe Number & IR Imager Reading $\left({ }^{\circ} \mathbf{C}\right)$ & Temperature Probes $\left({ }^{\circ} \mathbf{C}\right)$ \\
\hline 1 & 32.0 & 32.08 \\
2 & 32.1 & 32.47 \\
3 & 31.1 & 30.79 \\
4 & 32.2 & 31.1 \\
\hline
\end{tabular}

\subsection{Theory}

\section{- Calculation of Rates of Degradation of PV Modules}

The rate of degradation for performance parameters ( $\mathrm{P}_{\max }, \mathrm{I}_{\mathrm{SC}}, \mathrm{V}_{\mathrm{OC}}, \mathrm{FF}$ and PPF) were computed using the formula reported in the literature [24]:

$$
\begin{gathered}
\mathrm{P}_{\max \text { drop }}=\frac{\left(\text { Manufacturer rated } \mathrm{P}_{\max }-\text { measured power }\right)}{\text { Manufacturer rated } \mathrm{P}_{\max }} \times 100 \% \\
\mathrm{P}_{\max } \text { Degradation rate }(\mathrm{Rd})=\frac{\left(\mathrm{P}_{\max \text { drop }}\right)}{\text { years of operation }(\text { age })} \\
\mathrm{I}_{\mathrm{SC} \text { drop }}=\frac{\left(\text { Manufacturer rated } \mathrm{I}_{\mathrm{SC}}-\text { measured } \mathrm{I}_{\mathrm{SC}}\right)}{\text { Manufacturer rated } \mathrm{I}_{\mathrm{SC}}} \times 100 \% \\
\mathrm{I}_{\mathrm{SC}} \text { Degradation rate }=\frac{\mathrm{I}_{\mathrm{SC} \text { drop }}}{\text { years of operation }(\text { age })} \\
\mathrm{V}_{\mathrm{OC} \text { drop }}=\frac{\left(\text { Manufacturer rated } \mathrm{V}_{\mathrm{OC}}-\text { Present Day } \mathrm{V}_{\mathrm{OC}}\right.}{\text { Manufacturer rated } \mathrm{V}_{\mathrm{OC}}} \times 100 \% \\
\text { Degradation Rate }(\text { Rd })=\frac{\text { percentage of Voltage drop }\left(\mathrm{V}_{\mathrm{m} \text { drop }}\right)}{\text { years of operation }(\mathrm{age})} \\
\text { Fill Factor }(\mathrm{FF})=\frac{\text { Imp } \times \mathrm{Vmp}_{\mathrm{SC}} \times \mathrm{V}_{\mathrm{OC}}}{\mathrm{I}_{\mathrm{S}}} \\
\text { PPF }=\frac{\text { Present day value }}{\text { Manufacturer rated power }} \times 100
\end{gathered}
$$

\section{Results and Discussion}

The results of the visual inspection reported in our earlier paper (Quansah et al. [19]) and reproduced here in Table 2 did not show any major visually observable defects.

Table 2. Summary of results of visual inspection.

\begin{tabular}{cl}
\hline Component & \multicolumn{1}{c}{ Observation (s) } \\
\hline Cell gridlines & $\begin{array}{l}\text { Gridlines on modules indicate browning and corroding effect. These corrosion effects were } \\
\text { observed clearly on some gridlines of Modules } 1,5,6,12,13 \text { and } 14 \text { as shown in Figure } 5 \text { for } \\
\text { Module } 12\end{array}$ \\
\hline Backsheet & $\begin{array}{l}\text { Minor discoloration on front glass - this might be due to moisture ingress. No wavy texture } \\
\text { was observed, no chalking, burn marks or other damage was visible }\end{array}$ \\
\hline Wires/connectors & no embrittlement or burns was observed \\
\hline Delamination & Minor delamination was observed on Modules 1, 5, 6 and 7 \\
\hline Cell Gaps & All modules cell gaps showed minor brown discoloration, affecting encapsulations slightly \\
\hline Frames & $\begin{array}{l}\text { Frames of all modules show minor discoloration, there was no evidence of corrosion of } \\
\text { metal joints }\end{array}$ \\
\hline
\end{tabular}


Table 2. Cont.

\begin{tabular}{cl}
\hline Component & \multicolumn{1}{c}{ Observation (s) } \\
\hline Metallization & Bus-bars and cell interconnects showed no burns, discoloration or corrosion \\
\hline Junction box & No damage was observed on the junction boxes. No adhesion losses \\
\hline Interconnect Ribbons & Module 10 shows a minor burn along a ribbon (Figure 6) \\
\hline Front Glass & Animal droppings and dust particles observed before experiment was conducted \\
\hline
\end{tabular}

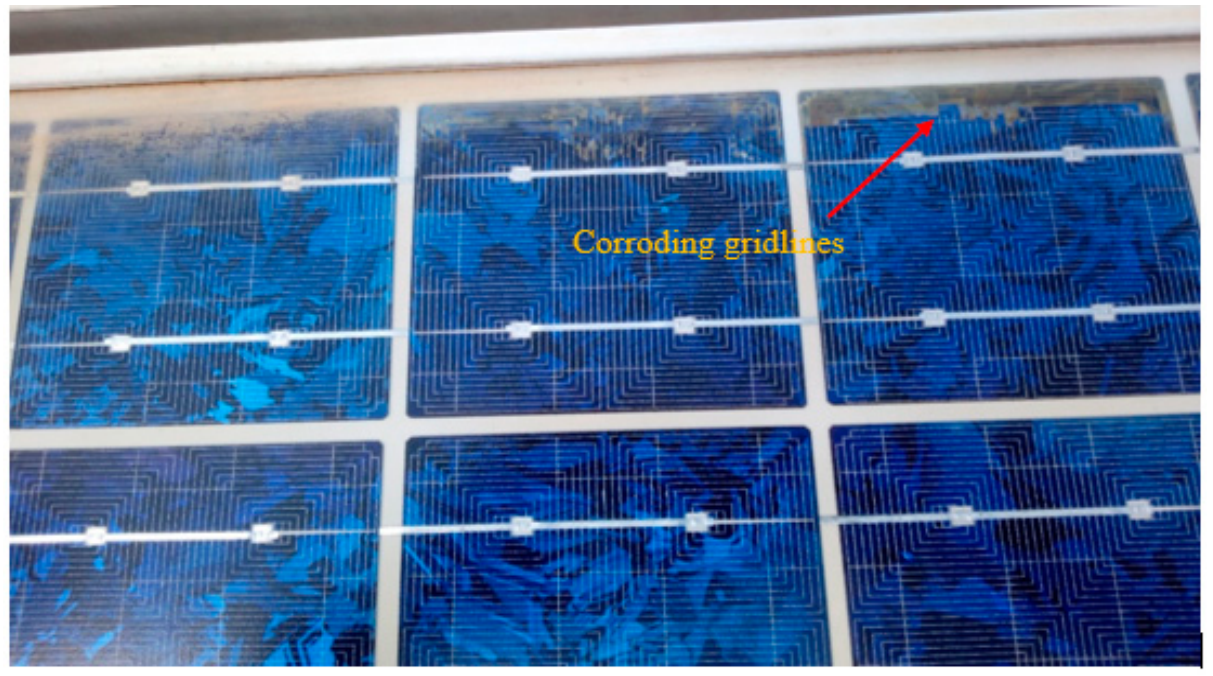

Figure 5. Module 12, indicating corroding gridlines.

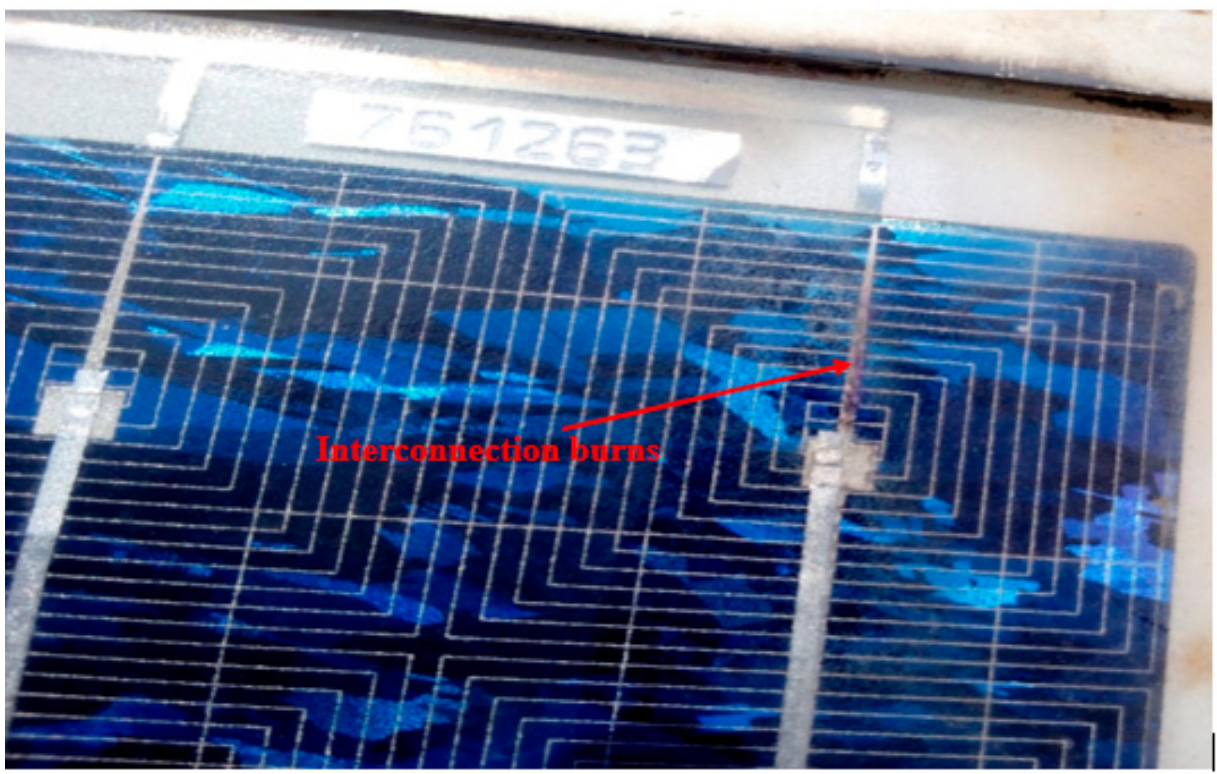

Figure 6. Module 10, indicating interconnection burns.

\subsection{Analysis of Experimental I-V Curves}

As indicated earlier in Section 2 (Methodology), all recorded data were extrapolated to STC conditions that will be used in the analysis. Figure 7 (Modules 1-14) shows curves traced from all 14 modules. 

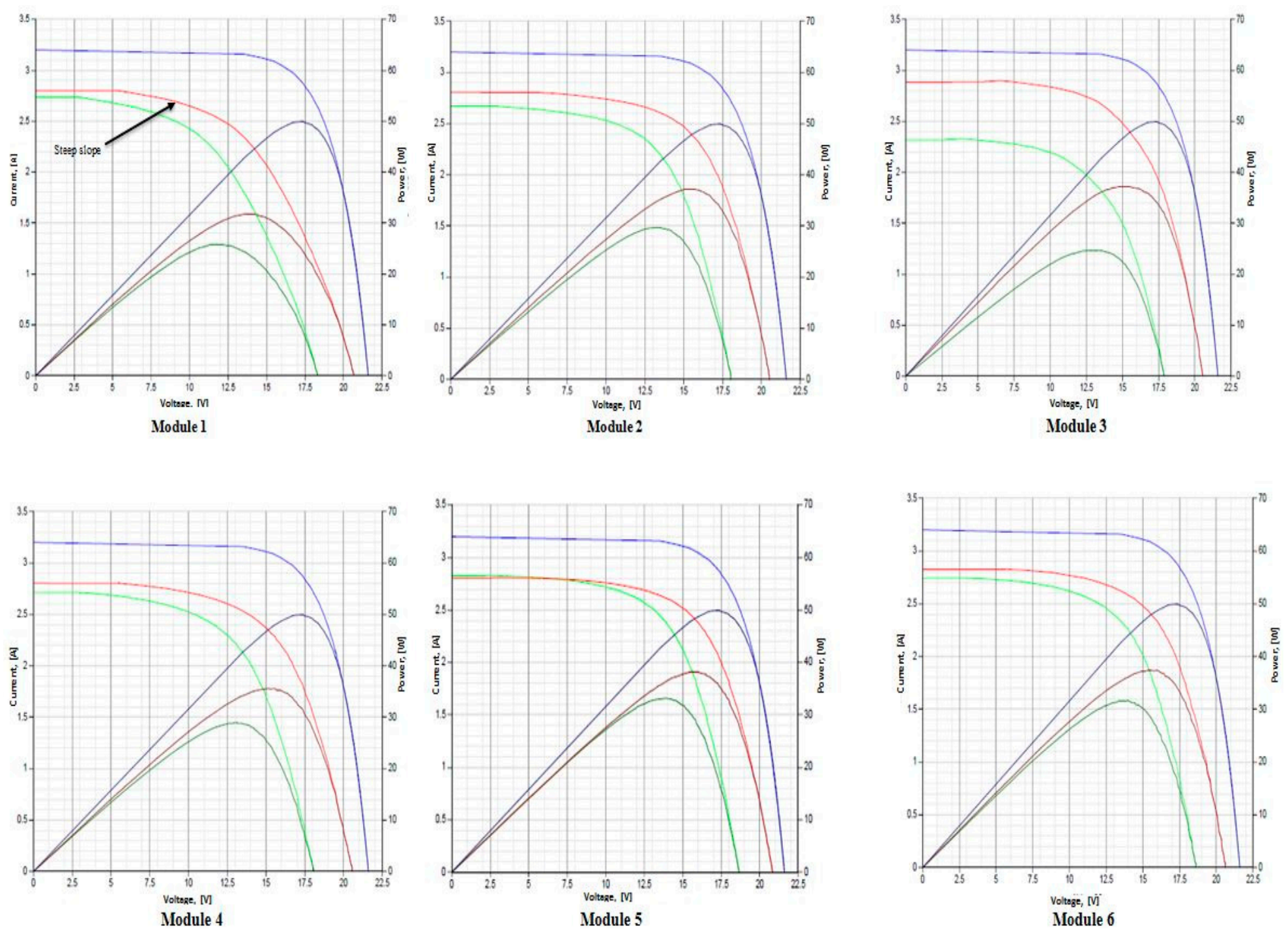

Figure 7. Cont. 

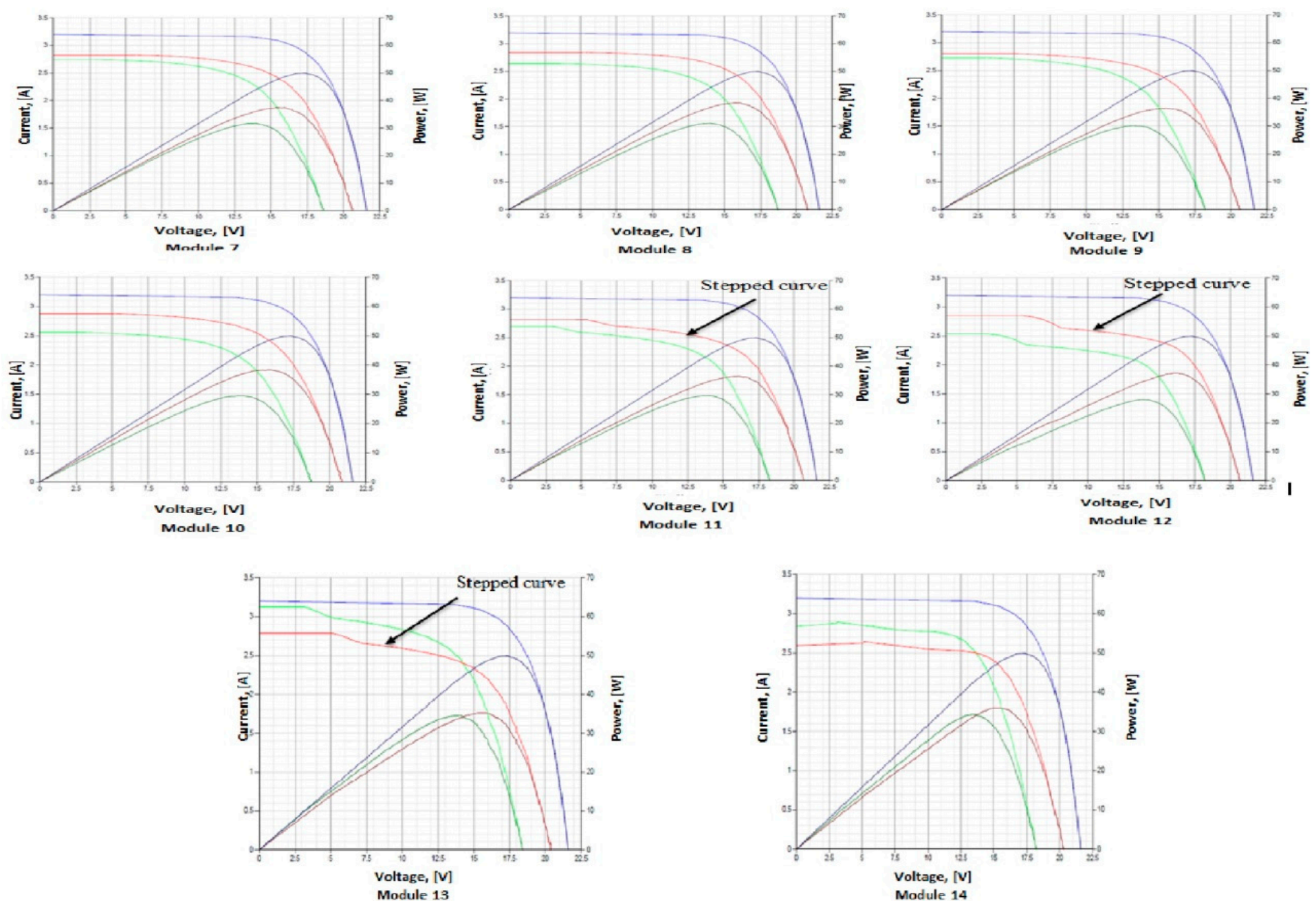

$$
\text { — Raw }
$$

Figure 7. I-V and power graphs showing raw, extrapolated and manufactures' Curves (Modules 1-14). 


\section{i. I-V Curves with Steep Slope}

Module 1 in Figure 7 shows a steep slope deviating sharply from the ideal plots than the manufacturer's plot. The effect has manifested in the reduction in the fill factor values (see Table 3). It is not clear the reason for this observed behaviour. The results also show a decrease in $\mathrm{V}_{\mathrm{OC}}$ and Isc values as compared with the manufacturer's curves. This is an indication of degraded modules.

Table 3. Results of module performance parameters from I-V tests.

\begin{tabular}{|c|c|c|c|c|c|c|c|}
\hline \multirow{2}{*}{$\begin{array}{l}\text { Module } \\
\text { Number }\end{array}$} & $P_{\max }$ (Watts) & $\mathrm{V}_{\max }$ (Volts) & $I_{\max }$ (Amps) & V OC (Volts) & ISC $_{\text {(Amps) }}$ & Fill Factor & PPF (\%) \\
\hline & 50 & 17.2 & 2.9 & 21.6 & 3.2 & 0.72 & 100 \\
\hline M 1 & 31.8 & 13.7 & 2.33 & 20.7 & 2.8 & 0.55 & 64 \\
\hline M 3 & 37.2 & 15.0 & 2.49 & 20.6 & 2.8 & 0.64 & 75 \\
\hline M 4 & 35.6 & 15.1 & 2.35 & 20.6 & 2.8 & 0.62 & 71 \\
\hline M 5 & 38.1 & 15.6 & 2.44 & 20.9 & 2.8 & 0.65 & 76 \\
\hline M 7 & 37.4 & 15.4 & 2.44 & 20.7 & 2.8 & 0.64 & 75 \\
\hline M 8 & 38.6 & 16.1 & 2.39 & 20.8 & 2.9 & 0.65 & 77 \\
\hline M 9 & 36.5 & 15.4 & 2.37 & 20.6 & 2.8 & 0.63 & 73 \\
\hline M 10 & 38.4 & 15.9 & 2.42 & 20.9 & 2.9 & 0.64 & 77 \\
\hline M 11 & 36.5 & 16.1 & 2.26 & 20.7 & 2.8 & 0.62 & 73 \\
\hline M 12 & 37.1 & 16.3 & 2.28 & 20.7 & 2.9 & 0.63 & 74 \\
\hline
\end{tabular}

\section{ii. Stepped I-V Curve}

From Figure 7, it can be observed that Modules 11-13 show stepped I-V curves, a deviation from the manufacturer's ideal curve. Factors such as damaged PV cells or a short-circuited bypass diode may be the cause, according to the literature [13]. This is indicated by the significant drop in power (27 watts, 26 watts and 30 watts, respectively), as shown in Table 4. Inspections conducted on these PV modules indicated no physical defect except for a semi-permanent dirt deposit around the sloppy edges of the modules.

Table 4. Hot spot test results and degradation rates.

\begin{tabular}{cccccccc}
\hline $\begin{array}{c}\text { Module } \\
\text { Number }\end{array}$ & $\begin{array}{c}\text { Hottest } \\
\text { Spot }\left({ }^{\circ} \mathbf{C}\right)\end{array}$ & $\begin{array}{c}\text { Coldest } \\
\text { Spot }\left({ }^{\circ} \mathbf{C}\right)\end{array}$ & $\begin{array}{c}\text { Difference } \\
\left({ }^{\circ} \mathbf{C}\right)\end{array}$ & $\begin{array}{c}\mathbf{P}_{\text {drop }} \\
(\text { Watt })\end{array}$ & $\begin{array}{c}\mathbf{P}_{\text {deg }} \\
(\% / \text { year })\end{array}$ & $\begin{array}{c}\mathbf{I}_{\text {SC deg }} \\
(\% / \text { year })\end{array}$ & $\begin{array}{c}\mathbf{V}_{\text {OC deg }} \\
(\% / \text { year }\end{array}$ \\
\hline M 1 & 67 & 43 & 24 & 36 & 1.82 & 0.62 & 0.21 \\
M 2 & 56 & 44 & 12 & 26 & 1.29 & 0.63 & 0.24 \\
M 3 & 57 & 44 & 13 & 26 & 1.28 & 0.57 & 0.23 \\
M 4 & 58 & 44 & 14 & 29 & 1.44 & 0.62 & 0.23 \\
M 5 & 59 & 44 & 15 & 24 & 1.19 & 0.61 & 0.16 \\
M 6 & 58 & 44 & 14 & 30 & 1.52 & 0.86 & 0.2 \\
M 7 & 55 & 41 & 14 & 25 & 1.26 & 0.58 & 0.21 \\
M 8 & 48 & 40 & 9 & 23 & 1.15 & 0.54 & 0.18 \\
M 9 & 56 & 42 & 14 & 27 & 1.35 & 0.63 & 0.24 \\
M 10 & 56 & 41 & 14 & 23 & 1.16 & 0.54 & 0.17 \\
M 1 & 49 & 40 & 9 & 27 & 1.36 & 0.56 & 0.2 \\
M 12 & 51 & 42 & 9 & 26 & 1.29 & 0.55 & 0.22 \\
M 13 & 54 & 41 & 13 & 30 & 1.48 & 0.65 & 0.27 \\
M 14 & 54 & 42 & 12 & 28 & 1.39 & 0.67 & 0.3 \\
\hline
\end{tabular}

Figure 8 shows the I-V curves of five experiments taken for Module 1 in order to test for repeatability. It shows the various plots indicated as M1T1-M1T5 (experiments 1-5 for Module 1) for the manufacturer's data, STC condition and raw data (blue, green and red plots, respectively, shown in Figure 7). The plots show repeatable data. 


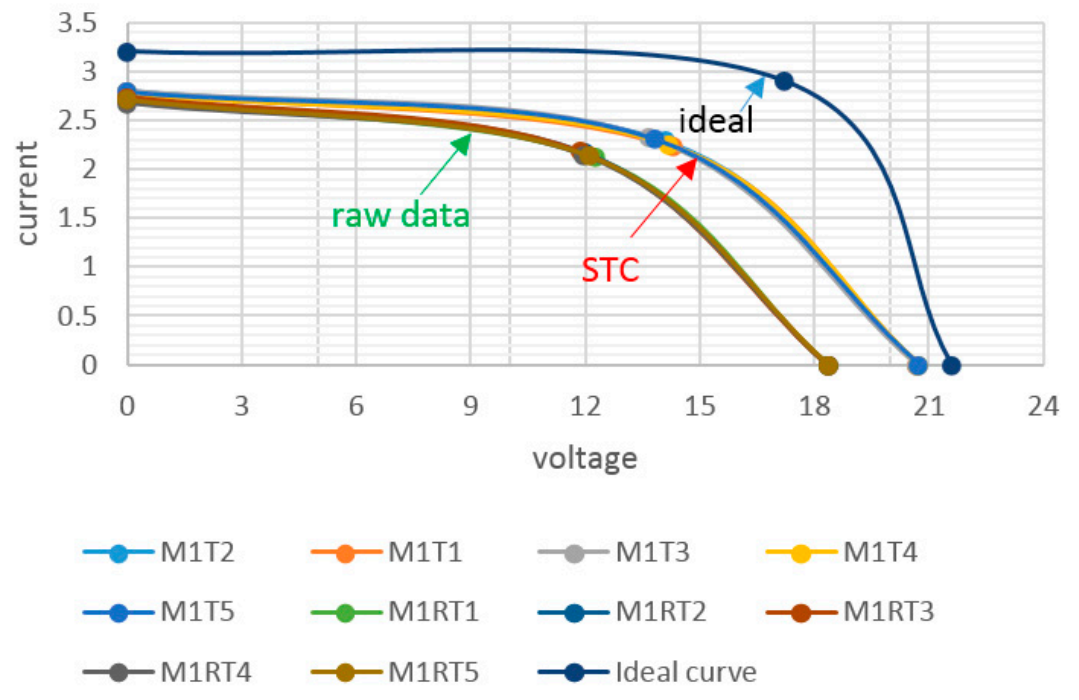

Figure 8. I-V curves of Module 1 to test for repeatability.

As indicated in Table 3, Module 1 recorded the least power output $\left(\mathrm{P}_{\max }\right)$ and voltage at maximum power $\left(\mathrm{V}_{\max }\right)$. This affects the overall performance of the module, as is evident in the fill factor and power performance factor results since Vmp directly affects the fill factor according to Equation (7). This is confirmed by the high rate of degradation (1.82\%/year) indicated in Table 4 .

\subsection{Infrared Imaging}

Table 4 shows the results of the infrared thermal tests and percentage (\%) degradation rates.

As shown in Table 4, Module 1 recorded the highest temperature difference of $24^{\circ} \mathrm{C}$. In the literature $[13,25]$, it is reported that a temperature difference above $20^{\circ} \mathrm{C}$ is evidence of a possible decrease in shunt resistance in a module and also evidence of module degradation. This further confirms the reason for the observed steeper I-V curve and also the lower fill factor value of 0.55 shown in Table 3. In a similar study in the literature [26], it is indicated that hot spots could be attributed to cracks and the heat generation can lead to cell delamination [21]. Defective cells and bypass diodes lead to hot spot generation on PV modules according to the work reported by researchers in [25]. In the same study the authors concluded that when the temperature difference is above $20^{\circ} \mathrm{C}$, it indicates a defective module; when it is between 10 and $20^{\circ} \mathrm{C}$, the effective power drop should be considered in determining whether the module is defective or not. If it is higher than the allowable drop according to the manufacturer's specifications, then it is defective; when it is below $10^{\circ} \mathrm{C}$, it is generally non-defective, unless if there is evidence of a bypass diode defect that may lead to a reduction in $\mathrm{I}_{\mathrm{SC}}, \mathrm{V}_{\mathrm{OC}}$ or power loss according to the work reported in $[25,27]$.

Modules 8, 11 and 12 show hot spot differences below $10^{\circ} \mathrm{C}$. These modules show relatively low $I_{S C}$ and $V_{O C}$ degradations. The rest of the modules $(2-7,9,10,13,14)$ show hot spot differences of $10-20{ }^{\circ} \mathrm{C}$. These modules show higher I $\mathrm{ISC}_{\mathrm{C}}$ and $\mathrm{V}_{\mathrm{OC}}$ degradation rates. Based on the above definitions, Modules 2-7, 9, 10, 13, and 14 can be considered defective.

Figure 9 shows that portions of select modules $(1,8-12)$, as captured by the IR thermal imager, show temperature hot spots. In the IR imaging tests, the coldest and hottest parts of the module were recorded and the difference determined, as shown in Table 3. A temperature difference of $10-20^{\circ} \mathrm{C}$ or more indicates a hot spot of an area. 


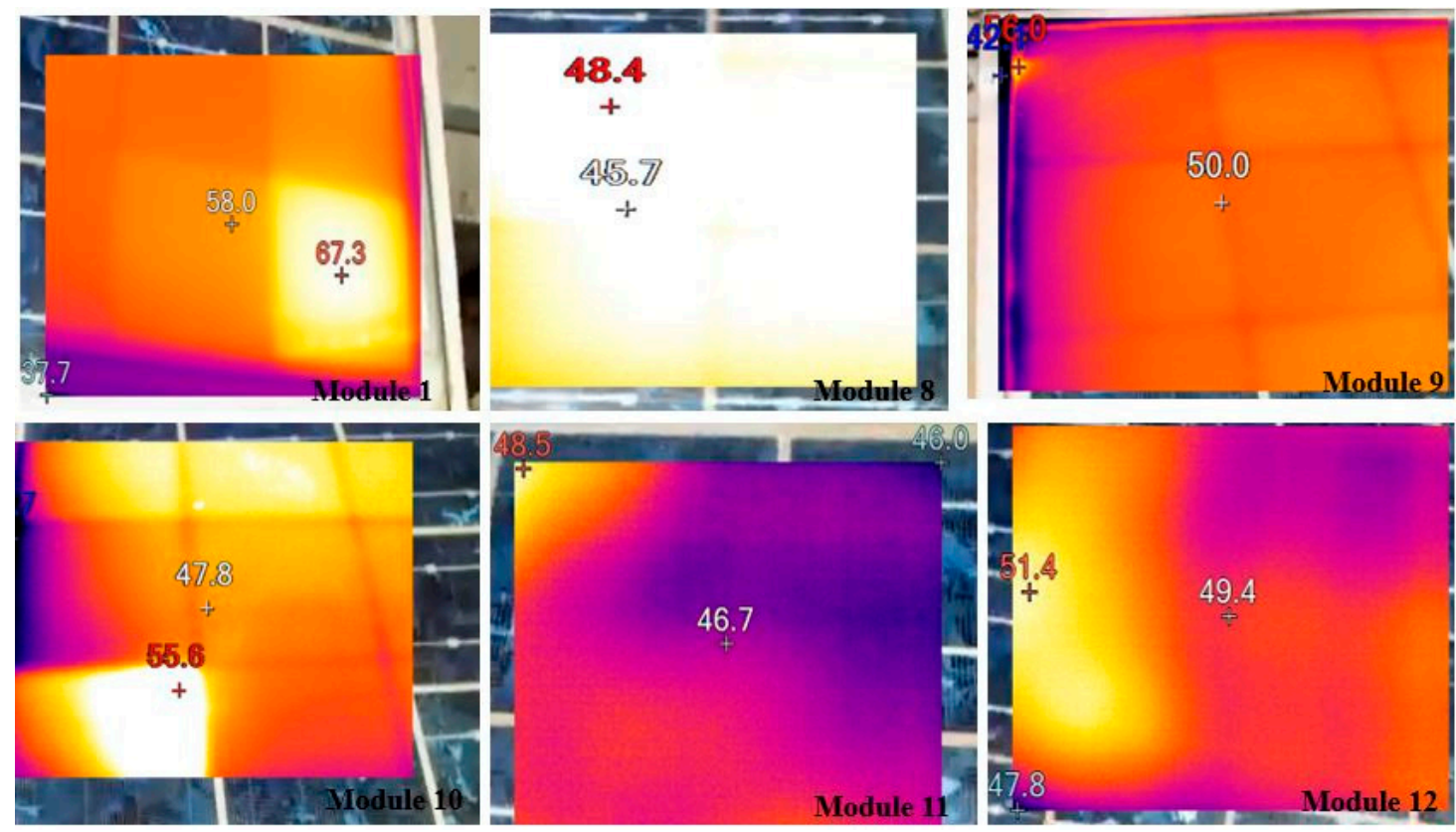

Figure 9. Thermal images of selected modules showing temperature hot spots.

\subsection{Module Degradation Rate and Power Drop}

From Table 4, the module power degradation using the manufacturer's rated data (50 watts) instead of the actual data at the time of installation (zero age) ranges between $1.19 \%$ and $1.823 \%$ /year, which is higher than the industry-accepted rate of $0.7 \%$ /year reported in the literature [6] or 1\%/year in earlier years reported in the work by Sample [28]. This indicates that all the modules tested fell outside the acceptable range of $0.7-1.0 \%$ degradation rate. Module 1 recorded the highest degradation rate of $1.82 \%$. The range of power performance factor (PPF) is $63.54-76.76 \%$ after 20 years of operation. This also indicates that all the modules' power output performance fell below the average $80 \%$ standard set by most manufacturers for modules operating within a 25 -year warranty. These factors indicate an overall higher degradation rate for all modules. Figure 10 shows the graph of degradation rate against number of years in operation. The graph also shows Module 1 with the highest degradation rate.

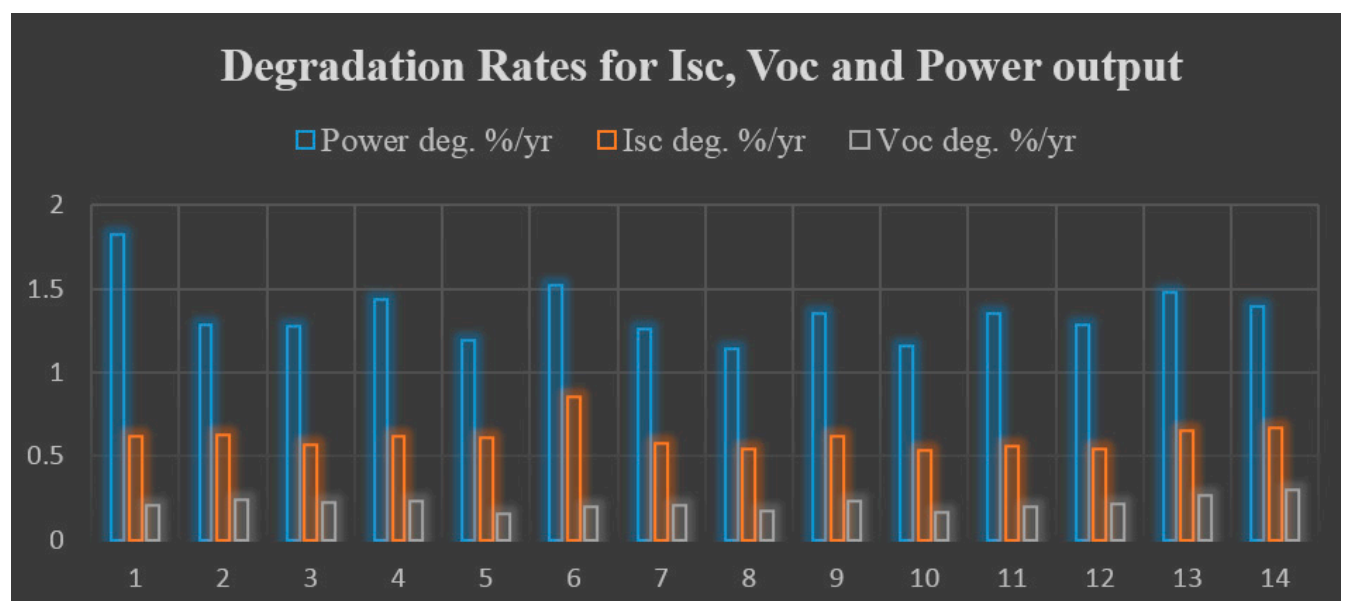

Figure 10. Degradation rates of 14 PV modules. 
Figure 11a-c shows the plots of temperature difference against $\mathrm{P}_{\mathrm{deg}}, \mathrm{PPF}$ and $\mathrm{P}_{\mathrm{drop}}$, respectively. The results show positive correlations, although not strong ones (R-values of $0.7,0.74$ and 0.74 ) between temperature difference and the performance parameters: $\mathrm{P}_{\mathrm{deg}}$, PPF and $\mathrm{P}_{\text {drop }}$. The three plots also show Module 1, separated from all other modules with the bulk of the data points concentrated around the same area near the best fit line.

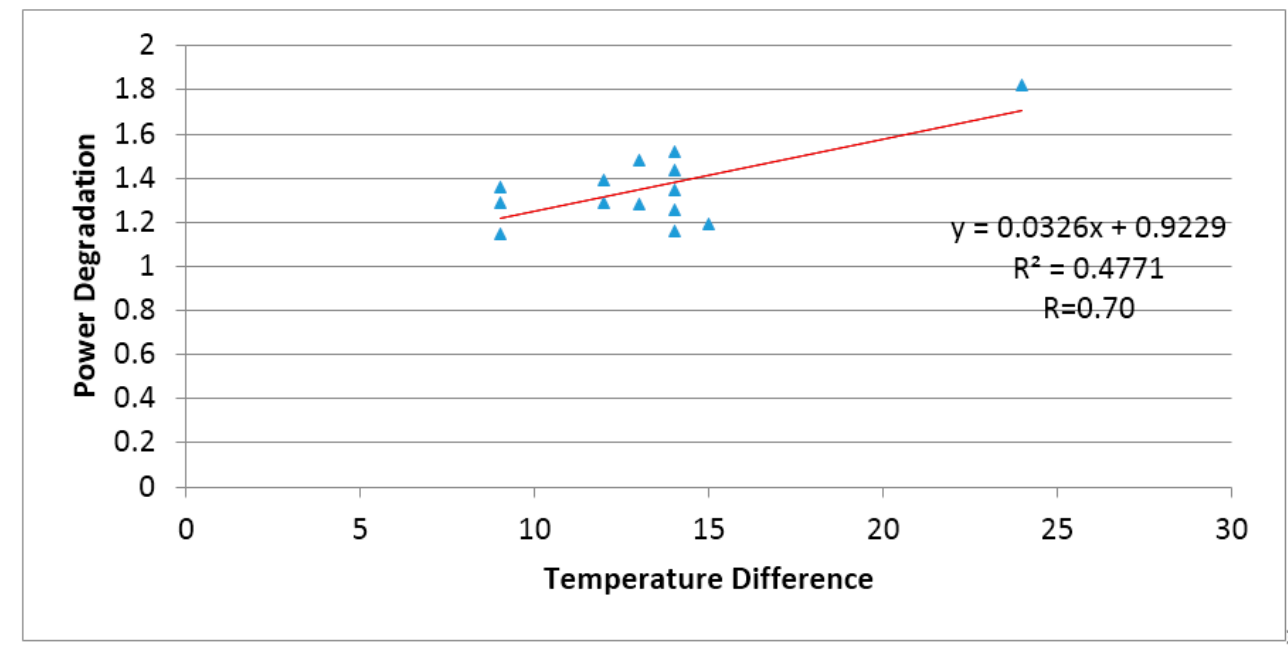

(a)

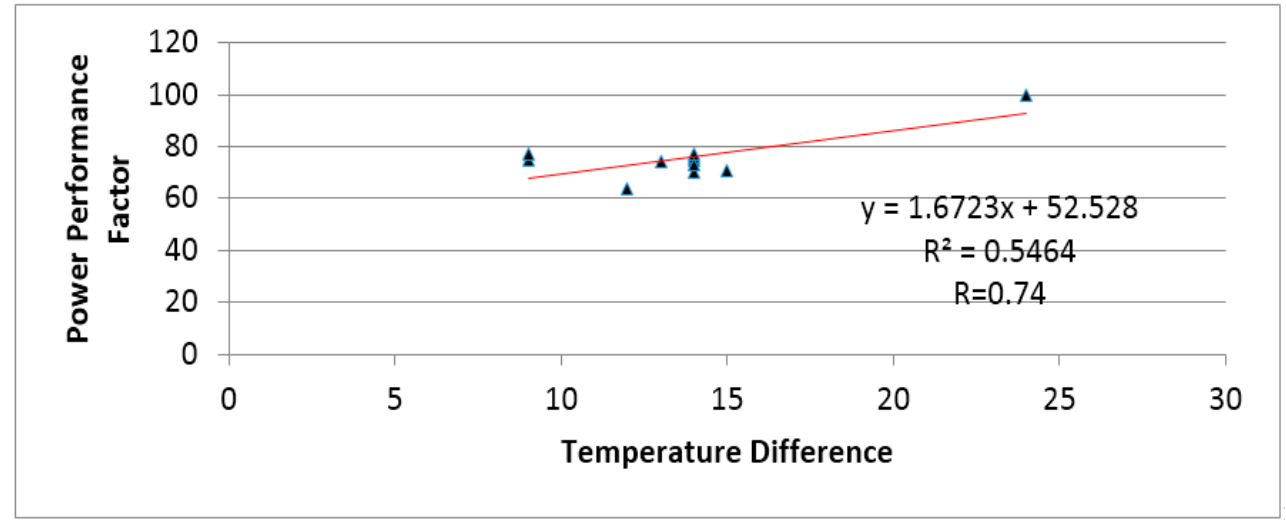

(b)

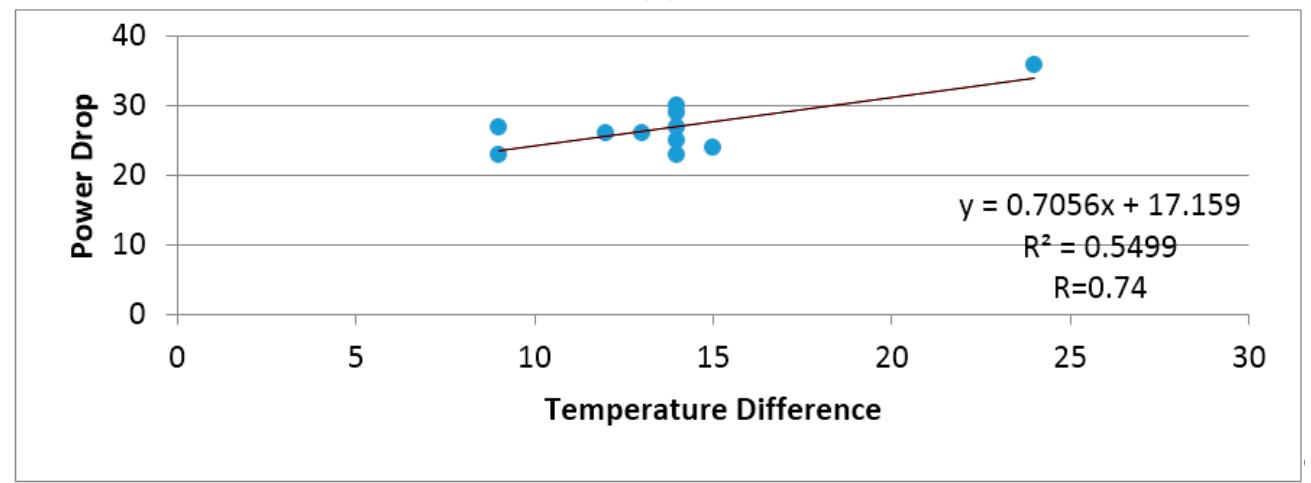

(c)

Figure 11. Graphs of temperature difference vs. $P_{\text {deg }}, P P F$ and $P_{\text {drop. }}$ (a) Temperature difference vs. $\mathrm{P}_{\mathrm{deg}} ;(\mathbf{b})$ temperature difference vs. PPF; (c) temperature difference vs. $\mathrm{P}_{\text {drop. }}$.

Table 5 shows the rate of degradation computed using $+10 \%$ and $-10 \%$ of the manufacturer's rated power of 50 watts. This is important because we were unable to obtain actual data forof the modules at the time of installation 20 years ago (zero age) and therefore have to use the manufacturer's rated 
data, which has been used in the literature [24]. The assumption here is that the actual data is $\pm 10 \%$ of the manufacturer's rated data. From Table 5, the rate of degradation of all the modules falls outside the recommended range of $0.7-1.0 \%$ / year if $+10 \%$ of the manufacturer's rated power of 50 watts is assumed. However, if $-10 \%$ of the manufacturer's data is assumed, only Modules 1, 6 and 13 fall outside the range.

Table 6 shows the efficiency results obtained for the STC conditions and other irradiance values $\left(800-1000 \mathrm{~W} / \mathrm{m}^{2}\right)$ using Equation (9). The efficiency at STC conditions was $10.75 \%$, whilst that at 981 , 922 and $833 \mathrm{~W} / \mathrm{m}^{2}$ irradiance was $6.7 \%, 7.4 \%$ and $6.8 \%$, respectively.

$$
\text { Efficiency }(\eta)=\frac{\text { Power }(\text { Nameplate }(W))}{1000 \mathrm{~W} / \mathrm{m}^{2} \times \text { Surface Area }\left(\mathrm{m}^{2}\right)}
$$

Table 5. Rate of degradation using $\pm 10 \%$ of manufacturer's rated power (50 watts).

\begin{tabular}{ccc}
\hline Module Number & $\begin{array}{c}\mathbf{- 1 0 \%} \text { of Manufacturer's } \\
\text { Rated (50 Watts) \%/year }\end{array}$ & $\begin{array}{c}\mathbf{+ 1 0 \%} \text { of Manufacturer's } \\
\text { Rated (50 Watts) \%/year }\end{array}$ \\
\hline M1 & 1.4 & 2.1 \\
M2 & 0.9 & 1.6 \\
M3 & 0.9 & 1.6 \\
M4 & 1.0 & 1.8 \\
M5 & 0.8 & 1.5 \\
M6 & 1.1 & 1.8 \\
M7 & 0.8 & 1.6 \\
M8 & 0.7 & 1.5 \\
M9 & 0.9 & 1.7 \\
M10 & 0.7 & 1.5 \\
M11 & 0.9 & 1.5 \\
M12 & 0.9 & 1.6 \\
M13 & 1.1 & 1.8 \\
M14 & 0.9 & 1.7 \\
\hline
\end{tabular}

Table 6. Data for efficiency determination.

\begin{tabular}{|c|c|c|}
\hline Power (Watts) & Irradiance $\left(\mathrm{W} / \mathrm{m}^{2}\right)$ & Efficiency (\%) \\
\hline 31.65 & 922 & 7.4 \\
\hline 26.29 & 833 & 6.8 \\
\hline 30.76 & 981 & 6.7 \\
\hline 50 (nameplate rating at STC conditions) & 1000 & 10.75 \\
\hline
\end{tabular}

Area of module $=0.465 \mathrm{~m}^{2}$.

\section{Conclusions}

In this study, the performance of 14 polycrystalline PV modules installed at the College of Engineering, KNUST, Kumasi (a hot, humid region of sub-Saharan Africa) with outdoor exposure of 20 years were evaluated. All the test modules came from the same manufacturer and were of the same model. The evaluation process involved I-V characterization and performance analyses, visual inspection and thermal imaging to detect hot spots.

The major conclusions from the study can be summarised as follows:

- The higher the temperature difference in the hot spot test, the higher the rate of power degradation. The modules that showed areas with high hot spots (a temperature difference of more than $10{ }^{\circ} \mathrm{C}$ ) generally showed a higher power drop and higher degradation rates. One module (Module 1) had a temperature difference above $20^{\circ} \mathrm{C}$ and 10 modules were between $10-20^{\circ} \mathrm{C}$. According to the criteria indicated in the literature, these 11 modules will fail the hot spot tests. The results 
provide evidence of a positive correlation between temperature difference and the performance parameters $\left(\mathrm{P}_{\text {deg }}, \mathrm{PPF}\right.$ and $\left.\mathrm{P}_{\text {drop }}\right)$.

- No external damage was observed on the module surfaces during the visual inspection, thus problems must be attributed to internal causes, with corrosion being one possible candidate. Electroluminescence imaging analysis can be conducted in the future to obtain detailed information on these defects.

- All 14 modules tested had an average power degradation rate of $1.36 \%$, higher than the industrially accepted range (0.7-1\%/year) when the manufacturer's rated power of 50 Watts was used in the computation instead of the actual data (measured at zero age). Module 1, with the highest temperature difference of $24^{\circ} \mathrm{C}$ in the hot spot test, also recorded the highest degradation rate of $1.82 \%$. This shows a strong correlation between the I-V test results and the hot spot test results. Within the 20 years of operation, the average power performance factor (PPF) (output power) was $72.9 \%$, lower than the $80.2 \%$ recommended by the manufacturer under the 25 year operation warranty claim statements. This indicates highly degraded modules. Several factors may account for this rate of degradation, which may not be attributed to manufacturing errors.

- When $+10 \%$ of the manufacturer's rated power of 50 watts was used, all 14 modules fell outside the acceptable range of $0.7-1.0 \%$. However, when $-10 \%$ was used, only three modules fell outside the range. These results also show a positive correlation between the I-V data and the hot spot tests results when the manufacturer's rated power was used as well as $+10 \%$ of the manufacturer's rated power.

Acknowledgments: The author would like to acknowledge Mani and Sai Tatapudi of ASU for the technical assistance and access to the ASU Polytechnic PRL (photovoltaic reliability laboratory). Financial support provided by USAID PEER Science under the PRESSA Project to provide technical support in terms of training at Arizona State University, USA and laboratory equipment to help set up the Ghana PRL at the College of Engineering, KNUST are highly appreciated. Finally, the assistance provided by teaching assistants at the Brew-Hammond Energy Centre, KNUST, in particular Jacob Owusu, Jr., is highly appreciated.

Conflicts of Interest: The author declares no conflict of interest.

\section{Nomenclature}

VOC Open Circuit Voltage (volts)

ISC Short Circuit Current (amps)

$P_{\max } \quad$ Maximum Power (watts)

FF $\quad$ Fill Factor

PPF Power Performance Factor

${ }^{\circ} \mathrm{C} \quad$ Temperature measured in degrees Celsius

NREL National Renewable Energy Laboratory

\section{References}

1. National Renewable Energy Laboratory (NREL). Analysis of Photovoltaic System Energy Performance Evaluation Method; NREL: Lakewood, CO, USA, 2013.

2. Jordan, D.C.; Kurtz, S.R. Photovoltaic Degradation Rates-An Analytical Review, Progress in Photovoltaics: Research and Application; NREL: Lakewood, CO, USA, 2011.

3. National Renewable Energy Laboratory (NREL). Outdoor PV Module Degradation of Current-Voltage Parameters; NREL: Lakewood, CO, USA, 2012.

4. Phono Solar Technology Co., Ltd. Limited Warranty for PV-Modules; Phono Solar Technology Co., Ltd.: Nanjing, China, 2016.

5. Tsanakas, J.A.; Chrysostomou, D.; Botsaris, P.N.; Gasteratos, A. Fault dignostis of photovoltaic modules through image processing and Canny edge detection on field thermographic measurements. Int. J. Sustain. Energy 2015, 34, 351-372. [CrossRef] 
6. Canadian Solar. Limited Warranty Statement: Photovoltaic Module Products; Canadian Solar: Munich, Germany, 2017.

7. LG Solar. 25 Year Limited Warranty; LG Solar: Eschborn, Germany, 2014.

8. Jinko Solar. Limited Warranty for PV Modules; Jinko Solar: Unterschleissheim, Germany, 2016.

9. Kyocera. Limited Warranty for Kyocera Photovoltaic Module(s); Kyocera: Zurich, Switzerland, 2013.

10. Photowatt. Modules General Terms of Warranty_EDF ENR PWT; Photowatt: Bourgoin-Jallieu, France, 2016.

11. Roumpakias, E.; Bouroutzikas, F.; Stamatelos, A. On-site inspection of PV Panels, Aided by Infrared Thermography. Adv. Appl. Sci. 2016, 1, 53-62.

12. Parretta, A.; Bombace, M.; Graditi, G.; Schioppo, R. Optical degradatin of long-term, field-aged c-Si photovoltaic modules. Sol. Energy Mater. Sol. Cells 2005, 86, 349-364. [CrossRef]

13. Solmetric. Guide to Interpreting I-V Curves Measurements of PV Arrays; Solmetric: Sebastopol, CA, USA, 2011.

14. Kurtz, S.R.; Myers, D.; Townsend, T.; Whitaker, C.; Maish, A.; Hulstrom, R.; Emery, K. Outdoor rating conditions for photovoltaic modules and systems. Sol. Energy Mater. Sol. Cells 2000, 62, 379-391. [CrossRef]

15. Osterwald, C.R. Standards, Calibration, and Testing of PV Modules and Solar Cells. In Practical Handbook of Photovoltaics; National Renewable Energy Laboratory: Golden, CO, USA, 2012.

16. Carr, A.J.; Prior, T.A. A comparison of the performance of different PV module types in temperate climates. Sol. Energy 2004, 76, 285-294. [CrossRef]

17. Kang, G. Investigation of Aging Phenomenon and Power Drop Rate with Field Exposed PV Modules; EUPVSCE: Valencia, Spain, 2010.

18. Sharma, V.; Chandel, S.S. Performance and degradation analysis for long term reliability of solar photovoltaics systems: A review. Renew. Sustain. Energy Rev. 2013, 27, 753-767. [CrossRef]

19. Quansah, D.A.; Adaramola, S.A.; Takyi, G.; Edwin, I.A. Reliability and degradation of solar PV modules-Case study of 19-year-old polycrystalline modules in Ghana. Technologies 2017, 5, 22. [CrossRef]

20. Gallon, J.; Horner, G.S.; Hudson, J.E.; Vasilyev, L.A.; Lu, K. PV Module Hotspot Detection; National Renewable Energy Lab: Golden, CO, USA, 2015.

21. Kumar, S.; Kumar, G. Hotspot analysis of photovoltaic module using EL and IR Techniques. Int. J. Adv. Eng. Res. 2012, 3, 62-65.

22. Hoyer, U. Analysis of PV modules by electroluminescence and IR thermography. In Proceedings of the 24 European Photovoltaic Solar Energy Conference, Hamburg, Germany, 21-25 September 2009.

23. Acciani, G.; Falcone, O.; Vergura, S. Typical defects of PV Cells. In Proceedings of the IEEE International Symposium on Industrial Electronics (ISIE), Bari, Italy, 4-7 July 2010.

24. Moorthy, M.K. Automation of Risk Priority Number Calculation of Photovoltaic Modules and Evaluation of Module Level Power Electronics. Master's Thesis, Arizona State University, Tempe, AZ, USA, 2015.

25. Moretón, R.; Lorenzo, E.; Leloux, J.; Carrillo, J. Dealing in practice with hotspots. In Proceedings of the 29th European Photovoltaic Solar Energy Conference and Exhibition, Amsterdam, The Netherlands, 22-26 September 2014.

26. Salazar, A.M.; Macabebe, E.Q.B. Hotspot Detection in Photovoltaic Modules Using Infrared Thermography. Electron. Power Syst. 2016, 70. [CrossRef]

27. Solar Edge. Technical Notes_Bypass Diode Effects in Shaded Conditions; Solar Edge: Hertsliya, Israel, 2010.

28. Sample, T. Failure modes and degradation rates from field-aged crystalline silicon modules. In Proceedings of the PV Module NREL Reliability Workshop, Denver, CO, USA, 16-17 February 2011.

(C) 2017 by the author. Licensee MDPI, Basel, Switzerland. This article is an open access article distributed under the terms and conditions of the Creative Commons Attribution (CC BY) license (http://creativecommons.org/licenses/by/4.0/). 